\title{
El Myudhotib
}

Jurnal Kajian Ekonomi dan Perbankan Syariah

Volume 2 Nomor 1 Juni 2021

E-ISSN: $2722-5615$

http://e-journal.iainfmpapua.ac.id/index.php/elmudhorib

\section{PENGARUH CITRA PERUSAHAAN, NILAI DAN HANDLING COMPLAINTERHADAP CUSTOMER RETENTION MELALUI KEPUASAN SEBAGAI VARIABEL INTERVENING}

\author{
Rohmatun Khasanah \\ IAIN Salatiga \\ rahma23khasanah@gmail.com
}

Received:

April 26, 2021

1st Revision:

July 07, 2021

Published:

July 31, 2021

\begin{abstract}
This study was conducted to determine the effect of corporate image, customer value and handling complain retention with satisfaction as intervening variables (case study on the customer of BNU Syariah Magelang) This research is quantitative research on customer data of this research is primary data. The sample used in this study is 95 customer. The sampling technique in this research itself is an icidental sampling technique method of analysis in this study using descriptif statical test, classical assumption test, statistical test, analisist path. The data obtained is then processed with SPSS16 tools. The result of this study show that the company's image has a positive and insignificant effect on the customer's satisfaction and the handling of complaint positive ang significant effect on the company's customer's satisfaction. the handling complaint and customer satisfaction positive and unrosenign of cistome rerennon value of a positive and significant auction of the cementis reference in this research satisfaction is unable to mediate the encoding between the customer's company's custom and handling complain against customer retention of resellerne complaint.
\end{abstract}

Keywords: Corporate Image, Customer Value, Handling Complain, Satisfaction, Customer Retention.

\footnotetext{
Abstrak

Penelitian ini dilakukan untuk mengetahui adanya pengaruh Citra Perusahaan, Nilai Nasabah Dan Handling Complain Terhadap Customer Retention Dengan Kepuasan Sebagai Variabel Intervening (Studi Kasus Pada Nasabah Bnu Syariah Magelang). Jenis Penelitian ini adalah penelitian kuantitatif. Data penelitian ini merupakan data primer. Sampel yang
} 
digunakan dalam penelitian ini adalah 95 nasabah. Teknik pengambilan sample dalam penelitian ini sendiri merupakan teknik sampling insidental. Metode analisis dalam penelitian ini menggunakan uji statistik deskriptif, uji asumsi klasik, uji statistik, path analysis. Data yang di peroleh kemudian diolah dengan alat bantu SPSS16. Hasil penelitian ini menunjukkan bahwa Citra Perusahaan berpengaruh positif dan tidak signifikan terhadap kepuasan. Nilai nasabah dan Handling Complain berpengaruh positif dan signifikan terhadap Kepuasan nasabah. Citra Perusahaan, Handling Complain dan Kepuasan pelanggan berpengaruh positif dan tidak signifikan terhadap Customer Retention. Nilai nasabah berpengaruh positif dan signifikan terhadap Customer Retention. Dalam penelitian ini Kepuasan tidak mampu memediasi pengaruh antara Citra Perusahaan, Nilai Nasabah dan Handling Complain terhadap Customer Retention.

Kata Kunci: Citra Perusahaan, Nilai Nasabah, Handling Complain, Kepuasan, Customer Retention.

\section{PENDAHULUAN}

Bank merupakan sebuah lembaga keuangan yang diharapkan dapat membantu kemajuan perkembangan perekonomian negara sebagai badan yang dapat menampung maupun menyalurkan dana kepada masyarakat agar sedikitnya dapat ikut menyejahterakan rakyat dengan lebih merata. Menurut Yudiana (2017) Perbankan memiliki fungsi sebagai lembaga yang menghimpun dana dari masyarakat dalam bentuk simpanan dan menyalurkannya kembali ke masyarakat dalam rangka meningkatkan taraf hidup rakyat banyak. Dalam hal ini BNU juga merupakan bank yang bergerak untuk ikut membantu perkembangan perekonomian. BNU Syariah 26 Magelang atau yang dikenal juga dengan Bank Meru Nusantara Mandiri Syariah kabupaten Magelang merupakan bank pengkreditan rakyat yang berdiri di bawah naungan NU. Sama halnya seperti bank-bank yang lain BNU sendiri juga memiliki beberapa permasalah terkait keterbatasan akses maupun transaksi yang pada akhirnya berdampak pada kembali atau tidaknya nasabah dalam membeli maupun menggunakan produk dari bank tersebut.

Kembalinya nasabah dalam menggunakan jasa maupun pembelian produk disebut dengan Customer retention (retensi pelanggan). Menurut Kotler (2009) Customer retention adalah pelanggan yang bertahan dengan keloyalitasannya serta berbicara hal positif kepada yang lain. Customer retention juga merupakan indikator dan sasaran yang penting untuk rekomendasi dari mulut ke mulut maupun meningkatkan pembelian berulang yang berdampak positif terhadap perusahaan (Hasan, 2013). Retensi pelanggan sendiri dapat dipengaruhi oleh beberapa hal salah satunya adalah citra perusahaan, nilai pelanggan dan bandling complain (keluhan pelanggan).

Dalam penelitian ini variabel mediasi di gunakan untuk menjadi faktor penghubung antara variabel dependen dengan variabel independen yang mana peneliti menggunakan faktor kepuasan sebagai variabel yang menghubungkan antara variabel citra perusahaan, nilai nasabah, dan keluhan 
pelanggan dengan variabel customer retention (retensi pelanggan). Kepuasan sendiri adalah bentuk dari perasaan senang yang diakibatkan suatu kenyataan berjalan lebih dengan baik atau bahkan lebih baik dari harapan sedangkan perasaan tidak puas adalah perasaan yang terbentuk karena suatu kenyataan berjalan buruk dan tidak sesuai harapan.

\section{KAJIAN LITERATUR}

\subsection{Customer Retention (Retensi Pelanggan)}

Customer retention (Retensi pelanggan) mengubah transaksi konsumen individu menjadi hubungan pelanggan jangka panjang dengan membuatnya dalam kepentingan terbaik pelanggan untuk tetap bersama perusahaan daripada beralih ke perusahaan lain (Schiffman, 2015). Customer retention juga merupakan indikator dan sasaran yang penting untuk rekomendasi dari mulut ke mulut maupun meningkatkan pembelian berulang yang berdampak positif terhadap perusahaan (Hasan, 2013).

\subsection{Kepuasan Nasabah}

Menurut Rangkuti (2002:30) kepuasan pelanggan adalah respon pelanggan terhadap kesesuaian atau ketidak sesuaian antara harapan dengan kinerja aktual yang dirasakan atau di presepsikan setelah pemakaian. Maka bisa di katakan apabila sebuah produk maupun pelayanan yang di harapkan bisa melebihi maupun sesuai dengan ekspektasi pelanggan dapat di katakan bahwa pelanggan itu merasa puas, begitu juga sebaliknya jika suatu produk maupun pelayanan tidak sesuai atau berasa di bawah ekspektasi pelanggan dapat dikatakan bahwa pelanggan merasa tidak puas.

Pada dasarnya bila seorang pelanggan merasa puas dengan suatu produk atau layanan yang didapat, maka pelanggan tersebut akan melakukan pembelian ulang pada apa yang didapatnya dan memungkinkan untuk menambah kuantitas dari pembelian (Solvang, 2007).

\subsection{Handling Complain}

Menurut James (2006:20) Keluhan adalah salah satu bagian dari ekspresi negatif yang di hasilkan karena ketidak sesuaian kenyataan dengan keinginan seseorang. Dwyer et al dalam Ndubisi (2017) mengatakan bahwa menangani konflik didefinisikan sebagai kemampuan pemasok untuk menghindari konflik potensial yaitu dengan mengatasi konflik potensial sebelum membentuk suatu masalah dan mendiskusikan solusinya secara terbuka ketika masalah timbul.

\subsection{Nilai Nasabah}

Menurut Woodall (2003) Nilai pelanggan sendiri di definisikan sebagai keseluruhan presepsi personal mengenai sebuah keuntungan yang akan diperoleh pelanggan berkaitan dengan adanya penawaran dari suatu perusahaan dan dapat di capai dengan mengurangi pengorbanan atau memberikan manfaat seperti yang diinginkan pelanggan. Maka dapat dikatakan bahwa nilai pelanggan merupakan pengevaluasian seorang konsumen kepada suatu bank atau perusahaan sesuai dengan produk maupun jasa yang telah mereka gunakan. 
Pengevaluasian tersebut bisa dilakukan seorang konsumen secara langsung maupun tidak langsung yang dilakukan dengan cara menilai secara menyeluruh antara apa yang diterima kemudian membandingkan dengan apa yang diharapkan, sehingga hal tersebut membentuk sebuah pandangan maupun presepsi terhadap baik buruknya perusahaan.

\subsection{Citra Perusahaan}

Menurut Jefkins (1995) Citra perusahaan merupakan citra dari suatu organisasi secara keseluruhan, bukan hanya melihat produk atau pelayanannya. Citra merupakan persepsi yang tidak mudah pembentukannya, jadi apabila sudah terbentuk maka akan sulit untuk diubah. Citra sendiri adalah hal yang cukup konsisten dalam jangka panjang, sehingga harus dibentuk dengan jelas dan memiliki keunggulan bila dibandingkan dengan pesaingnya (Simamora, 2007) .

Pada dasarnya citra tidak bisa dengan mudah ditanamkan dalam pikiran masyarakat hanya dalam waktu semalam. Oleh karena itu citra perlu secara terus menerus disebarkan melalui berbagai sarana komunikasi dan agar dapat mempertahankan maupun memperoleh konsumen maka semaksimal mungkin suatu perusahaan harus memperlihatkan citra yang positif terhadap pelanggan.

\subsection{Kerangka Penelitian}

Berdasarkan Landasan teori yang sudah dipaparkan maka kerangka penelitian yang dapat di susun mengenai pengaruh masing-masing variabel independen terhadap variabel dependen juga variabel intervening sebagai faktor penghubung di antara keduanya adalah sebagai berikut:

Gambar 2.1

\section{Kerangka Pemikiran Teoritik}

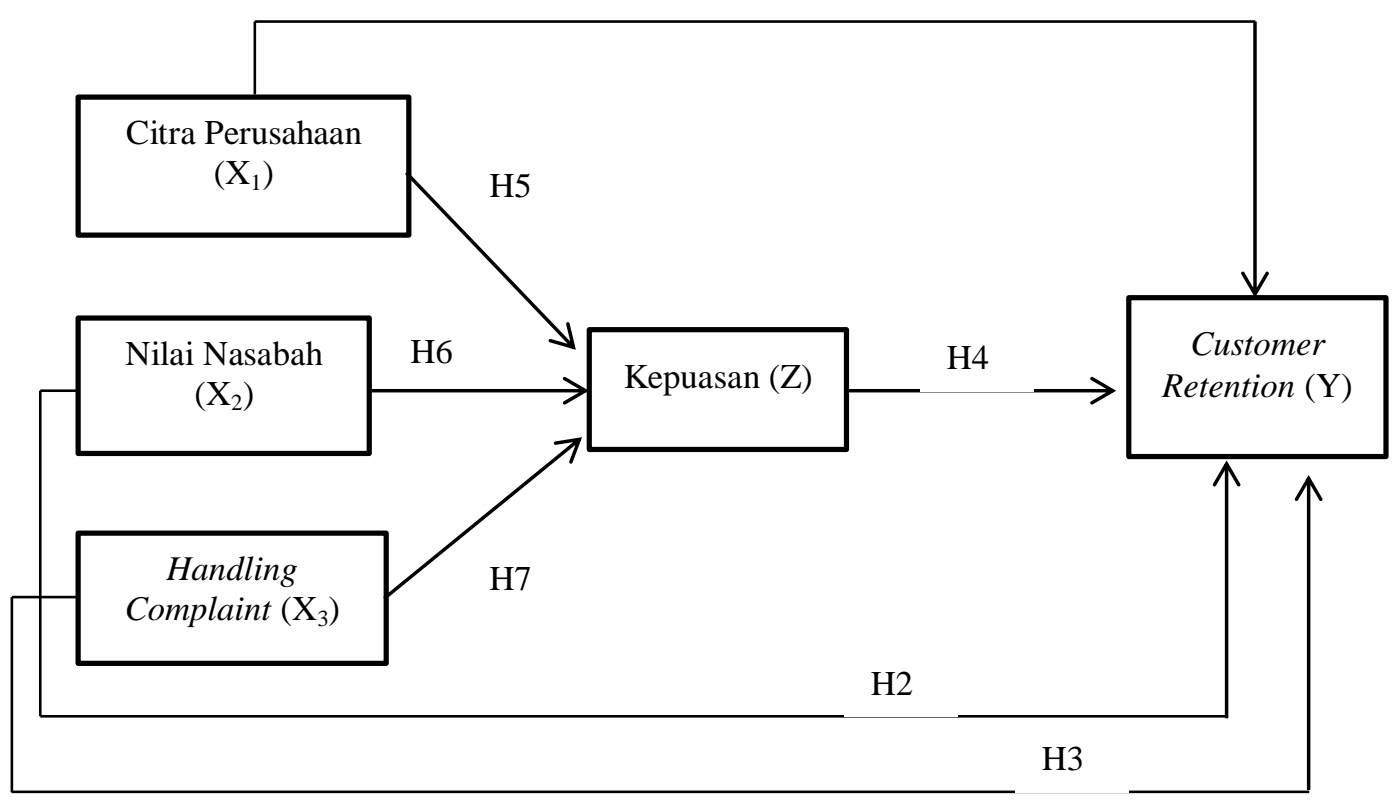




\section{Hipotesis.}

Hipotesis adalah jawaban sementara terhadap rumusan masalah penelitian, yang mana rumusan masalah penelitian dinyatakan dalam bentuk kalimat pertanyaan. Disebut sementara karena jawaban yang diberikan baru didasarkan pada teori relevan, belum didasari pada fakta-fakta empiris yang diperoleh melalui pengumpulan data. Maka hipotesis juga dinyatakan sebagai jawaban teoritis terhadap rumusan masalah penelitian, belum jawaban yang empirik (Sugiyono, 2016: 64). Dalam penelitian ini, hipotesis yang diajukan adalah:

$\mathrm{H}_{1}$ : Citra perusahaan berpengaruh positif dan signifikan terhadap customer retention.

$\mathrm{H}_{2}$ : Nilai pelanggan berpengaruh positif dan signifikan terhadap customer retention.

$\mathrm{H}_{3}$ : Handling complaint berpengaruh positif dan signifikan terhadap customer retention.

$\mathrm{H}_{4}$ : Kepuasan berpengaruh positif dan signifikan terhadap customer retention.

$\mathrm{H}_{5}$ : Kepuasan dapat memediasi pengaruh Citra perusahaan terhadap customer retention.

$\mathrm{H}_{6}$ : Kepuasan dapat memediasi pengaruh Nilai pelanggan terhadap customer retention.

$\mathrm{H}_{7}$ : Kepuasan dapat memediasi pengaruh handling complaint terhadap customer retention.

\section{METODE PENELITIAN}

\subsection{Populasi dan Sampel}

Jenis penelitian ini adalah penelitian lapangan yang menggunakan metode pendekatan kuantitatif. Penelitian kuantitatif juga disebut sebagai metode discovery karena dengan metode ini dapat di kembangan berbagai Iptek baru. Metode Kuantitatif sendiri merupakan penelitian yang berupa angka-angka dan analisis menggunakan statistik (Sugiyono, 2016).

\subsection{Populasi dan Sampel}

Populasi yang digunakan dalam penelitian ini, merupakan nasabah bank BNU Syariah Magelang sebanyak 2000 nasabah. Namun, sampel dari penelitian ini hanya diambil dari sebagian populasi.

Sampel yang digunakan dalam penelitian ini adalah nasabah bank BNU Syariah KC Magelang yang melakukan transaksi secara berulang. Teknik yang digunakan untuk menentukan jumlah sampel dalam penelitian ini dapat di rumuskan sebagai berikut:

Rumus Slovin:

$$
n=\frac{N}{1+N(e)^{2}}
$$

Keterangan:

$\mathrm{n}=$ jumlah sampel.

$\mathrm{N}=$ jumlah total populasi.

$\mathrm{e}=$ toleransi eror

Dari banyaknya populasi yang ada, maka perhitungan penentuan jumlah sampel pada nasabah bank BNU Syariah Magelang adalah sejumlah sampel yang di peroleh $\mathrm{n}=95$. 


\section{HASIL PENELITIAN DAN PEMBAHASAN}

\subsection{Hasil}

Uji Instrument Penelitian

Instrument penelitian yang digunakan untuk menganalisis data dalam penelitian ini adalah sebagai berikut:

\section{Uji Validitas}

Menurut Ghozali (2013) uji validitas merupakan uji yang digunakan untuk mengukur kevaliddan kuesioner. Suatu point dikatakan valid apabila pertanyaan yang tersusun pada sebuah kuesioner mampu mengungkap sesuatu yang akan diukur. Dalam penelitian ini pengukuran tingkat validitas tiap item kuesioner menggunakan Pearson Produk Moment. Semua pertanyaan yang digunakan dalam kuesioner pada penelitian ini dinyatakan valid, hal ini disebabkan karena data $\mathrm{r}$ hitung $>\mathrm{r}$ table (pada taraf signifikansi $\alpha=0,05$ ) sehingga data yang diperoleh dinyatakan valid (Ghozali, 2013).

\section{Uji Reliabilitas}

Sebuah kuesioner disebut reliabel atau handal apabila jawaban seorang responden terhadap pernyataan mengalami kekonsistenan atau stabil dari waktu ke waktu. Untuk mengukur apakah sebuah pertanyaan reliabel digunakan uji statistik Cronbach Alpha ( $\alpha$ ) yaitu dimana ketika suatu konstruk atau variabel memberikan nilai Cronbach Alpha $>0,60$ (Ghozali, 2013). Sehingga dapat diketahui bahwasanya variabel citra perusahaan, nilai nasabah, handling complain, kepuasan nasabah dan customer retention adalah reliabel dan dapat digunakan sebagai alat ukur variabel.

\section{Uji Multikolieneritas}

Uji multikolinearitas digunakan untuk menguji apakah dalam model regresi ditemukan adanya korelasi antar variabel independen. Hasil pengujian multikolinearitas sendiri menunjukkan bahwasanya nilai tolerance untuk variabel citra perusahaan (X1) adalah 0,598, nilai nasabah (X2) sadalah 0,498, bandling complain (X3) adalah 0,471, dan kepuasan nasabah (Z) adalah 0,455. Nilai tolerance yang diperoleh setiap variabel tersebut lebih dari 0,1. Nilai VIF untuk variabel citra perusahaan (X1) sendiri sebesar 1,671, nilai nasabah (X2) sebesar 2,007, handling complain (X3) sebesar 2,125, dan kepuasan nasabah (Z) sebesar 2,196, yangmana VIF pada masing-masing variabel memiliki nilai yang kurang dari 10. Berdasarkan hal tersebut, maka disimpulkan bahwa tidak terjadi adanya gejala multikolinearitas.

\section{Uji Heterokesdesitas}

Uji ini dilakukan untuk mengetahui apakah dalam sebuah model regresi terjadi adanya ketidaksamaan variabel residual dari satu pengamatan ke pengamatan yang lain. Adapun hasil 
ujinya menggunakan uji gletjser dan menunjukkan nilai signifikansi citra perusahaan sejumlah 0,326 nilai signifikansi nilai nasabah sejumlah 0,385, nilai signifikansi handling complain sejumlah 0,991 dan nilai signifikansi kepuasan nasabah sejumlah 0,785. Maka bisa dikatakan bahwa tidak terjadi adanya heteroskedastisitas karena semua nilai signifikansi yang ada dalam tabel, masing-masing dari variabel nilainya berada di atas 0,05 (Ghozali, 2013).

5. Uji Normalitas

Uji ini digunakan untuk mengetahui apakah dalam sebuah model regresi, variabel dependen \& independen yang dipakai dalam penelitian memiliki distribusi yang normal atau tidak, karena sebuah data penelitian dikatakan baik apabila datanya berdistribusi normal. Dari hasil uji statistik non-parametrik kolmogrov smirnov dapat diketahui bahwa Asymp.Sig (2-tailed) sejumlah 0,23 dengan tingkat signifikansinya sebesar 0,05 hasil ini menjelaskan bahwa data yang dipakai dalam penelitian berdistribusi normal, dikarenakan nilai Asymp.Sig (2-tailed) lebih besar dari nilai signifikansi 0,05 yaitu 0,312 .

Uji Statistik

\section{Koefisien Determinasi $\left(\mathbf{R}^{2}\right)$}

Pada dasarnya koefisien determinasi $\left(\mathrm{R}^{2}\right)$ digunakan untuk mengukur sejauh mana kemampuan suatu model dalam menjelaskan variasi dependen. Nilai dari koefisien determinasi adalah antara 0 dan 1 . Jika nilai $\mathrm{R}^{2}$ mendekati 1 maka dikatakan bahwa variabel independen memberikan hampir semua informasi yang dibutuhkan untuk memprediksi variabel dependen (Ghozali, 2013).

Dalam penelitian ini di ketahui bahwa koefisien determinasi (Adjusted $\mathrm{R}^{2}$ ) sebesar 0,410 ini berarti bahwa kontribusi variabel independen (citra perusahaan, nilai nasabah, handling complain, dan kepuasan nasabah) mempengaruhi adanya variabel dependen (customer retention) sebanyak 41\%, sedangkan 59\% nya merupakan pengaruh dari variabel lain yang berada di luar model.

2. Uji Signifikansi Simultan (Uji F)

Uji Statistik F pada dasarnya menunjukkan apakah semua variabel independen atau bebas yang dimasukkan dalam model mempunyai pengaruh secara bersama-sama terhadap variabel dependen atau terikat (Ghozali, 2013). Uji keseluruhan dapat dilakukan dengan menggunakan statistik $\mathrm{F}$ dimana diketahui bahwa $\mathrm{F}$ hitung dalam penelitian ini sejumlah 17,341 lebih besar dari $F$ tabel 2,14 dengan nilai signifikansinya 0,000. Nilai signifikansi tersebut kurang dari nilai alpha 0,05 dan menyatakan bahwa semua variabel independen secara bersama-sama mempengaruhi variabel dependen dengan signifikan.

3. Uji Parsial

Uji statistik t menunjukkan seberapa jauh pengaruh satu variabel penjelasan atau independen secara individual dalam menerangkan variasi variabel dependen. Dalam uji t jika Ho : bi $=0$ maka artinya suatu variabel independen bukan merupakan penjelasan yang signifikan 
terhadap variabel dependen dan jika $\mathrm{Ho}: \mathrm{bi} \neq 0$ maka artinya variabel tersebut merupakan penjelasan yang signifikan terhadap variabel dependen (Ghozali, 2013). Signifikansi koefisien parsial ini memiliki distribusi t dengan signifikansi $\alpha=0,5$ dan derajat kebebasannya adalah n-k-1.

Tabel 4.1 Hasil Uji Parsial (Uji t) I

\begin{tabular}{|c|c|c|c|c|c|c|}
\hline \multicolumn{7}{|c|}{ Coefficients ${ }^{\mathrm{a}}$} \\
\hline \multirow{2}{*}{\multicolumn{2}{|c|}{ Model }} & \multicolumn{2}{|c|}{$\begin{array}{l}\text { Unstandardized } \\
\text { Coefficients }\end{array}$} & \multirow{2}{*}{$\begin{array}{c}\begin{array}{c}\text { Standardized } \\
\text { Coefficients }\end{array} \\
\text { Beta }\end{array}$} & \multirow[b]{2}{*}{$\mathrm{T}$} & \multirow[b]{2}{*}{ Sig. } \\
\hline & & B & $\begin{array}{l}\text { Std. } \\
\text { Error }\end{array}$ & & & \\
\hline \multirow[t]{5}{*}{1} & (Constant) & 5,285 & 2,343 & & 2,256 & ,026 \\
\hline & $\mathrm{CP}$ & ,205 & , 149 & , 140 & 1,372 & , 174 \\
\hline & $\mathrm{NN}$ & ,412 & ,151 & ,306 & 2,724 & ,008 \\
\hline & $\mathrm{HC}$ & ,315 & ,184 & ,198 & 1,716 & ,090 \\
\hline & $\mathrm{K}$ & ,205 & ,169 & , 142 & 1,213 & ,228 \\
\hline
\end{tabular}

Sumber: Data Primer yang dolah, 2021

Tabel 4.2 Hasil Uji Parsial (Uji t) 2. q

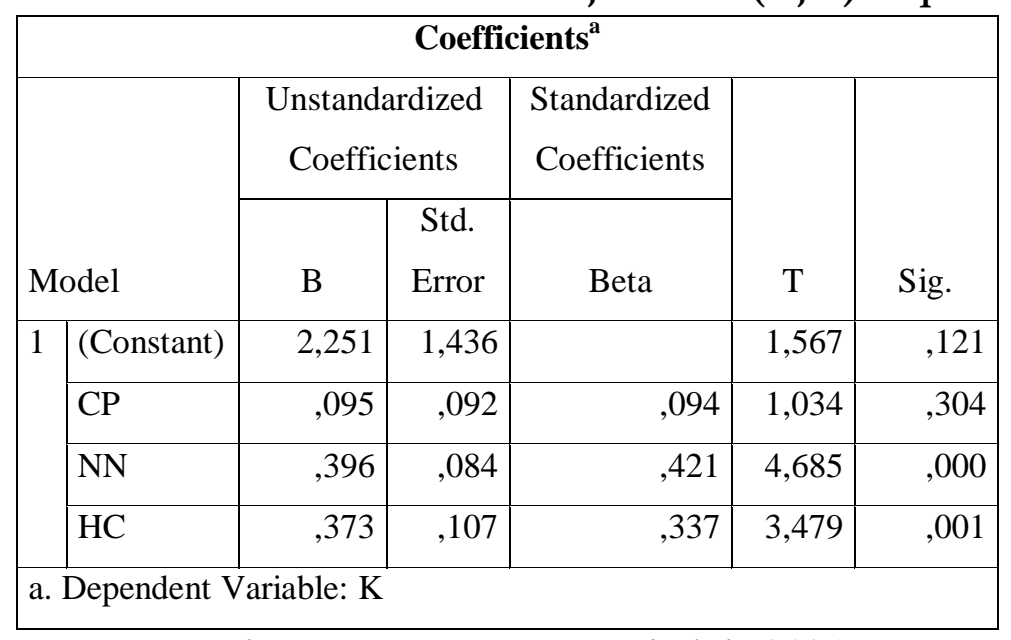

Sumber: Data Primer yang diolah, 2021

Berdasarkan dua tabel di atas, maka bisa dilihat jika nilai signifikansi yang jumlahnya kurang dari nilai alpha $(0,05)$ maka variabel tersebut akan dinyatakan sebagai variabel positif dan mempengaruhi variabel dependen. Berdasarkan dari hasil uji t maka diketahui bahwa

1) Variabel Citra Perusahaan (X1) secara parsial tidak memiliki pengaruh kepada variabel customer retention $(\mathrm{Y})$. 
2) Nilai pelanggan (X2) dapat disimpulkan bahwa secara parsial memiliki pengaruh positif dan juga signifikan pada variabel customer retention $(\mathrm{Y})$.

3) Handling complain (X3) secara parsial memiliki pengaruh yang positif tetapi tidak signifikan pada variabel customer retention $(\mathrm{Y})$.

4) Variabel kepuasan $(Z)$ secara parsial tidak memiliki pengaruh yang signifikan pada variabel customer retention $(\mathrm{Y})$.

5) Citra perusahaan (X1) tidak memiliki pengaruh yang signifikan terhadap kepuasan (Z)

6) Terdapat hubungan positif dan signifikan antara nilai nasabah (X2) dengan kepuasan (Z).

7) Terdapat hubungan yang positif dan signifikan antara handling complain (X3) dan kepuasan (Z).

\section{Analisis Jalur (Path Analysis)}

Untuk menguji adakah pengaruh dari variabel intervening sebagai variabel yang memediasi antara variabel dependen dan independen maka digunakan adanya metode analisis jalur (path analisi). Hasil analisis jalur secara lengkap dalam penelitian ini di jelaskan secara lebih rinci dalam gambar di bawah ini yaitu sebagai berikut:

\section{Gambar 4.1 Hasil Analisis Jalur}

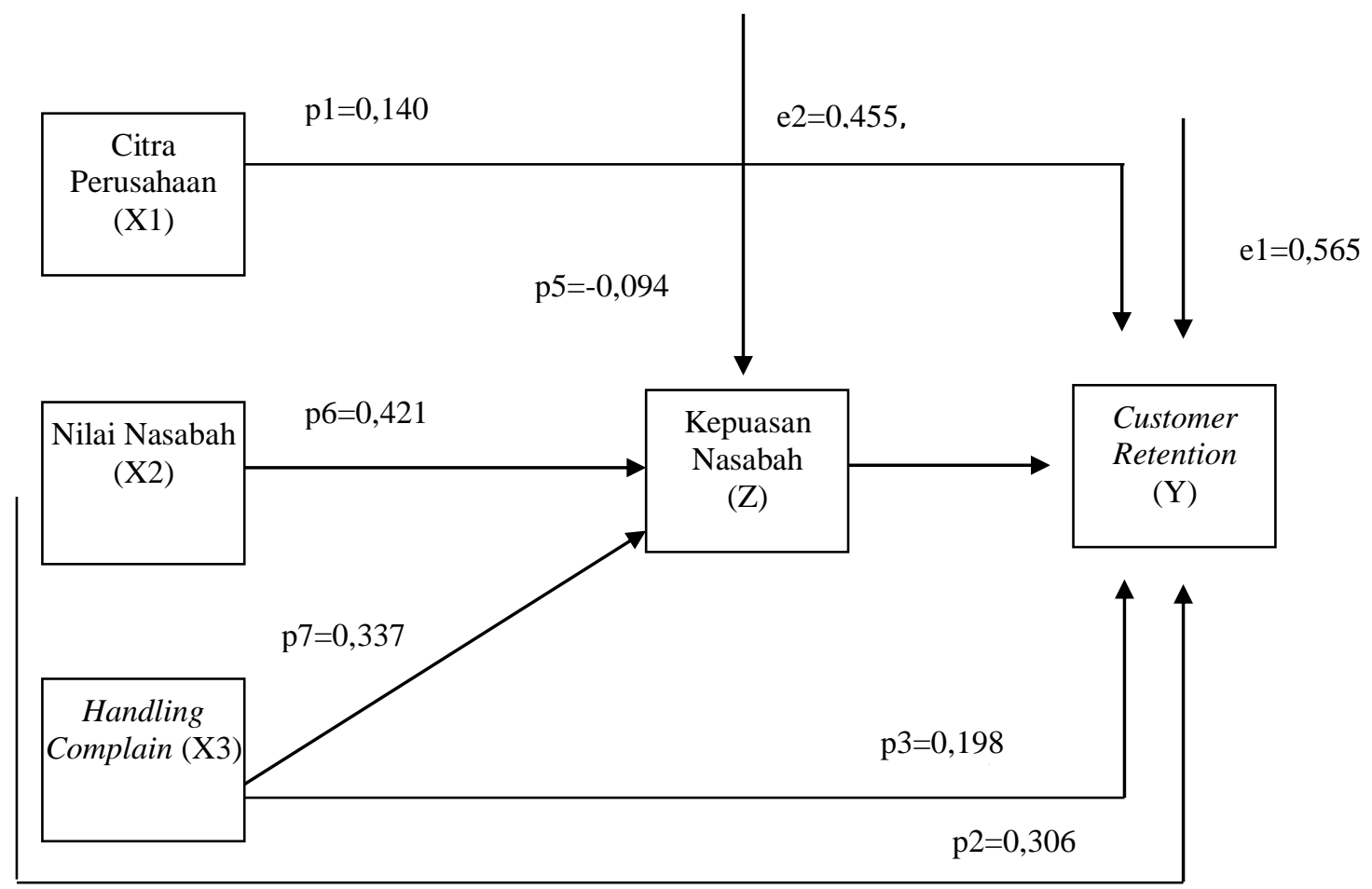

Berdasarkan gambar yang ada di atas, dapat kita ketahui terkait adanya pengaruh langsung maupun pengaruh tidak langsung, pengaruh total maupun pengaruh mediasi yang dilihat sengan menggunakan Sobel Test sebagai berikut: 
1) Pengaruh citra perusahaan terhadap customer retention dengan kepuasan nasabah sebagai variabel intervening.

Diketahui bahwasanya pengaruh langsung dari variabel citra perusahaan (X1) terhadap variabel customer retention $(\mathrm{Y})$ adalah sebesar 0,140 , pengaruh tidak langsungnya adalah sebesar 0,013348, pengaruh totalnya adalah sebesar 0153348 dan pengaruh tingkat mediasi yang dihitung dengan menggunakan Sobel test didapatkam T hitungnya sebanyak 15,6116959 dimana hasil tersebut lebih besar dari t tabel yang sebesar 1,98667 dengan tingkat signifikansinya adalah 0,05 atau 5\%, sehingga dapat disimpulkan bahwa variabel kepuasan nasabah dapat memediasi antara variabel citra perusahaan terhadap variabel customer retention.

2) Pengaruh nilai nasabah terhadap customer retention dengan kepuasan nasabah sebagai variabel intervening

Diketahui bahwasanya pengaruh langsung yang dimiliki variabel nilai nasabah (X2) terhadap variabel customer retention $(\mathrm{Y})$ adalah sebesar 0,306 , pengaruh tidak langsungnya adalah sebesar 0,059782, pengaruh totalnya adalah sebesar. 0,365782 dan pengaruh mediasi dengan Sobel Test didapatkan T hitungnya sebanyak 12,01195 dimana hasil tersebut lebih besar dari t tabel yang sebesar 1,98667 dengan tingkat signifikansinya adalah 0,05 atau 5\%, sehingga dapat disimpulkan bahwa variabel kepuasan nasabah dapat memediasi antara variabel nilai nasabah terhadap variabel customer retention.

3) Pengaruh handling compalian terhadap customer retention dengan kepuasan nasabah sebagai variabel intervening

Diketahui bahwasanya pengaruh langsung yang dimiliki variabel handling complain (X3) terhadap variabel customer retention $(\mathrm{Y})$ adalah sebesar 0,198 pengaruh tidak langsungnya adalah sebesar. 0,047854, pengaruh totalnya adalah sebesar. 0,245854 dan pengaruh mediasi dengan Sobel Test didapatkan T hitungnya sebanyak 10,00752 dimana hasil tersebut lebih besar dari t tabel yang sebesar 1,98667 dengan tingkat signifikansinya adalah 0,05 atau 5\%, sehingga dapat disimpulkan bahwa variabel kepuasan nasabah dapat memediasi antara variabel handling complain terhadap variabel customer retention.

\subsection{Pembahasan}

Pada dasarnya penelitian ini dilakukan untuk mengetahui adanya pengaruh antara variabel citra perusahaan, nilai nasabah dan bandling complain dalam meningkatkan customer retention pada nasabah di BNU Syariah magelang dengan kepuasan yang digunakan sebagai variabel intervening (penghubung). Berdasarkan dari hasil penelitian yang telah dilakukan sebelumnya, maka didapatkan adanya hasil uji hipotesis masing-masing variabel sebagai berikut:

\section{Citra perusahaan (X1) terhadap Customer retention (Y)}

Berdasarkan dari hasil pengujian $\mathrm{T}_{\text {test }}$ pengaruh dari variabel citra perusahaan (X1) terhadap customer retention (Y) diketahui nilai koefisiennya sebesar 0,140 dan tingkat signifikansinya sebesar 0,174 dimana nilai tersebut lebih besar dari 0,05 atau 5\%. Sehingga disimpulkan bahwasanya citra perusahaan (X1) memiliki pengaruh positif tetapi tidak signifikan terhadap customer retention (Y) pada BNU Syariah Magelang. Maka $\mathrm{H}_{1}$ ditolak. 
Gonroos dan Keller dalam Safitri (2016) mengatakan bahwa citra perusahaan merupakan persepsi dari suatu organisasi yang di rekam dalam memori konsumen dan bekerja sebagai filter yang mempengaruhi persepsi terhadap perusahaan. Namun, sepertinya hal ini tidak berpengaruh terhadap para nasabah BNU Syariah karena minimnya promosi dan pengenalan sehingga nasabah tidak terlalu memahami Bank itu sendiri.

Hal ini sejalan dengan penelitian yang di lakukan oleh Ratih (2009) bahwasanya tidak ada pengaruh antara citra perusahaan terhadap niat pembelian ulang dan justru tidak sejalan dengan penelitian yang dilakukan oleh Purnama Rusna (2020). yang menyatakan adanya hubungan positif dan signifikan antara citra perusahaan dengan pembelian ulang.

\section{Nilai Nasabah (X2) terhadap Customer Retention (Y)}

Berdasarkan dari hasil pengujian $\mathrm{T}_{\text {test }}$ pengaruh dari variabel nilai nasabah (X2) terhadap customer retention (Y) diketahui nilai koefisiennya sebesar 0,306 dan tingkat signifikansinya sebesar 0,008 dimana nilai tersebut lebih kecil dari 0,05 atau 5\%. Sehingga disimpulkan bahwasanya nilai nasabah (X2) memiliki pengaruh positif dan signifikan terhadap customer retention (Y) pada BNU Syariah Magelang. Maka $\mathrm{H}_{2}$ diterima.

Hal ini sesuai dengan Setyadarma et al., (2012) dan Darmawan et al., (2020) dalam penelitiannya menjelaskan bahwa nilai pelanggan memiliki pengaruh positif dan signifikan terhadap retensi pelanggan dan justru tidak sesuai dengan penelitian Adixio, Riko Firmawan dan Laila Saleh (2013) yang menyatakan bahwa nilai pelanggan tidak berpengaruh terhadap niat beli ulang.

\section{Handling Complain (X3) terhadap Customer Retention (Y)}

Berdasarkan dari hasil pengujian $\mathrm{T}_{\text {test }}$ pengaruh dari variabel handling complain (X3) terhadap customer retention (Y) diketahui nilai koefisiennya sebesar 0,198 dan tingkat signifikansinya sebesar 0,090 dimana nilai tersebut lebih kecil dari 0,05 atau 5\%. Sehingga disimpulkan bahwasanya handling complain (X3) memiliki pengaruh positif dan tidak signifikan terhadap customer retention (Y) pada BNU Syariah Magelang. Maka $\mathrm{H}_{3}$ ditolak

Hal ini sesuai dengan Lompoliuw, Pio dan Runtuwene (2019) dimana dalam penelitian tersebut menyatakan bahwa penanganan keluhan tidak berpengaruh terhadap customer retention dan justru tidak sesuai dengan Kurniawati (2018) dalam penelitiannya mengatakan bahwa penanganan keluhan secara parsial mempengaruhi customer retention.

\section{Kepuasan Nasabah (Z) terhadap Customer retention (Y)}

Berdasarkan dari hasil pengujian $\mathrm{T}_{\text {test }}$ pengaruh dari variabel kepuasan nasabah (Z) terhadap customer retention (Y) diketahui nilai koefisiennya sebesar 0,142 dan tingkat signifikansinya sebesar 0,228 dimana nilai tersebut lebih besar dari 0,05 atau 5\%. Sehingga disimpulkan bahwasanya kepuasan nasabah $(Z)$ memiliki pengaruh 
positif tetapi tidak signifikan terhadap customer retention (Y) pada BNU Syariah Magelang dengan begitu dikatakan bahwa $\mathrm{H}_{4}$ ditolak.

Menurut Rangkuti (2002:30) kepuasan pelanggan adalah respon pelanggan terhadap kesesuaian atau ketidak sesuaian antara harapan dengan kinerja aktual yang dirasakan atau di presepsikan setelah pemakaian. Namun, melihat adanya dampak dari keadaan lingkungan yang terjadi pada tahun 2020-2021 yaitu Covid-19 pada akhirnya kepuasan tidak begitu mempengaruhi adanya pembelian ulang (Customer retention) dikarenakan nasabah akan lebih mementingkan kebutuhan pribadi dulu daripada melakukan transaksi dengan lembaga keuangan.

Hal ini jelas tidak sesuai dengan Qonitat dan Sunarti (2018) dimana dalam penelitian tersebut menyatakan bahwa kepuasan pelanggan memiliki pengaruh yang positif dan signifikan terhadap customer retention.

5. Pengaruh Citra perusahaan (X1) terhadap Customer Retention (Y) dengan Kepuasan sebagai Variabel Intervening (Z)

Berdasarkan hasil dari Path Analysis dengan menggunakan uji Sobel Test, t hitungnya adalah sebesar 15,6116959 dimana hasil tersebut lebih besar dari t tabel yang sebesar 1,98667 dengan tingkat signifikansi 0,05 atau 5\%. Berdasarkan hal tersebut maka disimpulkan bahwasanya koefisien mediasi signifikan, yang artinya variabel kepuasan nasabah $(\mathrm{Z})$ dapat memediasi antara pengaruh variabel citra perusahaan (X1) dengan variabel customer retention (Y) pada BNU Syariah Magelang. Dengan begitu menjelaskan bahwa $\mathrm{H}_{5}$ diterima.

Hal ini jelas sesuai dengan penelitian yang dilakukan oleh Oktavianti, Maria Christina (2015) dimana dalam penelitiannya menyatakan bahwa kepuasan mampu memediasi adanya pengaruh citra perusahaan terhadap niat beli ulang.

6. Pengaruh Nilai Nasabah (X2) terhadap Customer Retention (Y) dengan Kepuasan Nasabah sebagai Variabel Intervening $(Z)$

Berdasarkan hasil dari Path Analysis dengan menggunakan uji Sobel Test, maka diperoleh hasil dari t hitungnya adalah sebesar 12,01195 dimana hasil tersebut lebih besar dari t tabel yang sebesar 1,98667 dengan tingkat signifikansi 0,05 atau 5\%. Berdasarkan hal tersebut maka disimpulkan bahwasanya koefisien mediasi signifikan, yang artinya variabel kepuasan nasabah (Z) dapat memediasi antara pengaruh variabel nilai nasabah (X2) dengan variabel customer retention (Y) pada BNU Syariah Magelang. Dengan begitu menjelaskan bahwa $\mathrm{H}_{6}$ diterima.

Hal ini juga sejalan dengan penelitian yang dilakukan oleh Gumilang, Inda (2018) dimana penelitian tersebut menyatakan bahwa kepuasan mampu memediasi adanya pengaruh nilai nasabah terhadap retensi pelanggan.

7. Pengaruh Handling Complain (X2) terhadap Customer Retention (Y) dengan Kepuasan Nasabah sebagai Variabel Intervening $(\mathrm{Z})$

Berdasarkan hasil dari Path Analysis dengan menggunakan uji Sobel Test, maka diperoleh hasil dari t hitungnya adalah sebesar 10,00752 dimana hasil tersebut lebih besar dari t tabel yang sebesar 1,98667 dengan tingkat signifikansi 0,05 atau 5\%. 
Berdasarkan hal tersebut maka disimpulkan bahwasanya koefisien mediasi signifikan, yang artinya variabel kepuasan nasabah (Z) dapat memediasi antara pengaruh variabel handling complain (X3) dengan variabel customer retention (Y) pada BNU Syariah Magelang. Dengan begitu menjelaskan bahwa $\mathrm{H}_{7}$ diterima.

Hal ini juga sejalan dengan penelitian yang dilakukan oleh Lay Nico Yudhinata., et, al (2018) dimana penelitian tersebut menyatakan bahwa kepuasan mampu memediasi adanya pengaruh handling complain terhadap customer retention.

\section{Kesimpulan dan Saran \\ Kesimpulan}

Berdasarkan pada hasil penelitian yang dilakukan terkait pengaruh citra perusahaan, nilai pelanggan, handling complain terhadap customer retention dengan kepuasan nasabah sebagai variabe intervening, maka penarikan kesimpulannya adalah sebagai berikut:

1. Citra perusahaan memiliki pengaruh yang positif tetapi tidak signifikan pada customer retention. Maka diketahui bahwasanya hasil tersebut tidak sejalan dengan hipotesis citra perusahaan yang berpengaruh positif dan juga signifikan pada customer retention, dimana artinya apabila citra perusahaan mengalamai peningkatanpun tidak akan mempengaruhi adanya customer retention.

2. Nilai pelanggan memiliki pengaruh positif dan signifikan terhadap customer retention. Maka diketahui hasil tersebut sejalan dengan hipotesis yang menyatakan bahwa nilai nasabah berpengaruh positif dan signifikan terhadap customer retention, dimana artinya apabila nilai pelanggan mengalamai peningkatan akan mempengaruhi adanya customer retention.

3. Handling complain memiliki pengaruh yang positif tetapi tidak signifikan terhadap customer retention. Maka diketahui bahwasanya hasil tersebut tidak sejalan dengan hipotesis yang menyatakan bahwa handling complain berpengaruh positif dan signifikan terhadap customer retention, dimana artinya apabila handling complain mengalami peningkatan tidak akan mempengaruhi adanya customer retention.

4. Kepuasan nasabah memiliki pengaruh positif tetapi tidak signifikan terhadap customer retention. Maka diketahui hasil tersebut tidak sejalan dengan hipotesis kepuasan nasabah yang berpengaruh positif dan juga signifikan pada customer retention, dimana artinya ketika kepuasan mengalamai peningkatan hal ini tidak akan mempengaruhi adanya customer retention.

5. Variabel kepuasan nasabah dapat memediasi variabel citra perusahaan terhadap variabel customer retention secara positif dan juga signifikan. Maka diketahui bahwasanya hasil ini sejalan dengan hipotesis kepuasan nasabah yang menyatakan bahwa variabel tersebut mampu memediasi variabel citra perusahaan pada variabel customer retention secara positif dan signifikan.

6. Variabel kepuasan nasabah dapat memediasi pengaruh variabel nilai pelanggan pada variabel customer retention secara positif dan juga signifikan. Maka diketahui bahwasanya hasil ini sejalan dengan hipotesis kepuasan nasabah yang menyatakan bahwa variabel tersebut mampu memediasi pengaruh variabel nilai pelanggan pada variabel customer retention secara positif dan juga signifikan. 
7. Variabel kepuasan nasabah dapat memediasi pengaruh variabel handling complain pada varaiabel customer retention secara positif dan juga signifikan. Maka diketahui bahwasanya hasil ini sejalan dengan hipotesis kepuasan nasabah yang menyatakan bahwa variabel tersebut mampu memediasi pengaruh varabel handling complain pada variabel customer retention secara positif dan juga signifikan.

\section{Saran}

Berdasarkan dari kesimpulan yang ada di atas, maka peneliti memberi sedikit saran yang dapat bermanfaat baik untuk perbankan maupun akademisi:

1. Bagi BNU Syariah Magelang

BNU Syariah Magelang perlu meningkatkan citra melalui promosi maupun kegiatan sosial dan tingkat pelayanan kepada nasabah agar dapat memberikan kepuasan pada nasabah dan kemudian meningkatkan minat pembelian ulang (retensi pelanggan). Citra dan pelayanan yang baik juga bisa digunakan sebagai alat untuk menraik nasabah baru maupun mempertahankan nasabah lama.

2. Bagi Penelitian Selanjutnya

Untuk penelitian selanjutnya diharapkan juga dapat menambahkan variabel lain sebagai penelitian seperti tingkat kualitas pelayanan, promosi atau personal selling karena masih banyak faktor lain yang juga dapat mempengaruhi customer retention dan belum diteliti pada penelitian ini.

\section{DAFTAR REFERENSI}

Adixio, Riko dan Laila Saleh. 2013. Pengaruh Kualitas Layanan dan Nilai Yang Dirasa terhadap Niat Pembelian Ulang melalui Mediasi Kepuasan Pelanggan Restoran Solaria di Surabaya. Journal of Business and Banking. Vol 3 No 2

Darmawan, Arifin dan Rianto. 2020. Studi Tentang Presepsi Nilai, Kepuasan Dan Retensi Pelanggan Kapal Penyeberangan Ujung-Kamal. Jurnal Baruna Horizon. Vol. 3 No. 1

Ghozali, Imam. 2013. Aplikasi analisis multivariat dengan program IBM SPSS Edisi 7. Semarang: Penerbit Universitas Diponegoro.

Inda, Gumilang. 2018. Pengaruh Pemasaran dan Nilai Pelanggan terhadap Retensi pelanggan melalui kepuasan pelanggan. Commerce jurnal ilmiah politeknik piksi input serang. Vol 6 No 1 hlm 4362.

James, A.O. 2006. Introducing to Information System. Jakarta: Salemba Empat.

Kurniawati dan Krismawintari. 2018. Pengaruh Pemasaran Relasional terhadap Kepuasan Konsumen dan Customer Retention pada Toko Herbal Angelo Store Ubud Bali. Jurnal Ekonomi dan Pariwisata. Vol. 13 No 1

Lay, Listiana dan Heriyadi. 2018. Analisis Pengaruh Service Quality, Personal Selling dan Complain Handling Melalui Satisfaction serta Trust terhadap Customer Retention. Jurnal Ekonomi Bisnis dan Kewirausabaan. Vol. 7 No. 2 
Lompoliuw, Pio dan Runtuwene. 2019. Faktor-Faktor yang Mempengaruhi Customer Retention di PT Erafon Mega Mall Manado. Jurnal Administrasi Bisnis. Vol. 9 No. 1

Ndubisi, Nelson. 2017. Relationship marketing and customer royalti. Jurnal Of Marketing. Vol. 25 No. 1 hlm 98-106

Oktavianti, Maria Chritina Dewi. 2015. Pengaruh Kualitas Layanan (Servqual) Citra Perusahaan (Corporate Image), dan Kepuasan pada Gethok Tular Positif serta Niat Beli Ulang (Studi Pada Penerbangan Berbiaya Rendah di Indonesia). Jurnal Ekonomi Manajemen. P1-15

Qonitat, Suyadi dan Sunarti. 2018. Pengaruh Kepuasan Pelanggan dan Switching Barriers dan Kepercayaan Merek terhadap Customer Retention. Jurnal Administrasi Bisnis (JAB). Vol. 55 No. 2

Ratih, Ida. 2009. Pengaruh Kinerja Produk dan Pelayanan Sumber Daya Manusia terhadap Niat Pembelian Ulang melalui Citra Perusahaan dan Kepuasan Pelanggan PT. Asuransi Jiwasraya. Ekuitas. Vol.13 No.2

Safitri, Erwina, Rahayu Mintarti dan Nur Khusniyah Indrawati. 2016. Pengaruh Kualitas Pelayanan dan Citra Perusahaan terhadap Kepuasan Pelanggan dan Loyalitas Pelanggan Service Center. Jurnal Ekonomi Bisnis. Vol. 21 No.1

Schiffman, L. G. 2015. Cunsomer Behavior. Edisi 11 Global. New Jersey: Pearson Education.

Simamora, Bilson. 2007.Memenangkan Pasar dengan Pemasaran Efektif dan Profitabel. Jakarta: PT. Gramedia Pustaka Utama

Solvang, B.K., 2007. 'Satisfaction, Loyalti and Repurchase: A Study Of Norwegian Customer of Furniture and Grocery Store. Journal of Customer Satisfaction, Dissatisfaction and Complaining Behavior. Vol. 2 No. 1 pp.110-122

Sugiyono. 2016. Metode Penelitian Kuantitatif, Kualitatif dan R\&D. Bandung: Alfabeta

Tjandra, Olivia., et al. 2016. Analisis Pengaruh Citra Perusahaan terhadap Loyalitas Pelanggan melalui Kepuasan Pelanggan sebagai Variabel Perantara di Restoran Boncafe Surabaya. Journal Hospitality dan Manajemen Jasa. Vol. 4 No. 1.

Tjiptono, Fandy. 2004. Stategi Pemasaran. Edisi kedua. Yogyakarta: Andi offset.

Tjiptono, Fandy. 2007. Strategi pemasaran. Yogyakarta: Andi offset

Tjiptono. F. 2014. Manajemen Jasa. Yogyakarta: Andi offset.

Zineldin, M. 2000. Total Relationship Management (TRM) and Total Quality Management (TQM). Management Auditing Journal. Vol 12 No 1-2 